\title{
Pengembangan Media Pembelajaran Fisika SMA Kelas XI Menggunakan Microsoft Excel 2010 Pada Pokok Bahasan Impuls dan Momentum
}

\author{
Dwi Kurnia Nugroho \\ Pendidikan Fisika Universitas Ahmad Dahlan \\ Surat-e: dnugroho36@yahoo.co.id
}

\begin{abstract}
Impuls dan Momentum merupakan salah satu materi pembelajaran fisika kelas XI SMA. Impuls dan momentum merupakan mata pelajaran fisika yang dalam proses pembelajaran materinya memerlukan penalaran serta gambarannyatadalam kehidupan. Faktor kejenuhan siswa serta siswa hanya terpaku pada rumus tanpa diikuti dengan penalaran merupakan permasalahan dalam mengajar fisika. Hal ini juga didukung dengan kurangnya sarana dan prasarana yang berdampak pada kurangnya inovasi serta kreativitas guru dalam mengajar. Oleh karena itu, perlu dikembangkan sebuah media pembelajaran sederhana yang dapat dibuat oleh guru dalam keterbatasan sarana dan prasarana serta dapat menjadi solusi dalam mengatasi kejenuhan siswa dalam belajar. Media pembelajaran ini dikembangkan menggunakan Microsoft Excel 2010. Tujuan penelitian ini adalah mengetahui langkah-langkah menyusun media pembelajaran berbasis Microsoft Excel 2010 pada pokok bahasan impuls dan momentum, serta mengetahui kelayakan media pembelajaran yang telah dikembangkan tersebut.
\end{abstract}

Media pembelajaran ini disusun mengacu pada model pengembangan ADDIE yakni Analysis, Design, Development, Implementation dan Evaluation. Program ini selanjutnya diuji oleh ahli materi, ahli media serta pengguna untuk menguji kelayakan berdasarkan kriteria yang ditentukan dan hasilnya diolah menggunakan black block test.

Hasil validasi menunjukkan bahwa program media pembelajaran yang telah dikembangkan dari segi materi memperoleh persentase sebesar $78,72 \%$,dari segi media memperoleh persentase sebesar $78,50 \%$ serta untuk penguna memperoleh persentase sebesar 76,66\%. Dari hasil persentase tersebut, media pembelajaran berbasis Microsoft Excel 2010 pada pokok bahasan impuls dan momentum tergolong dalam kategori baik, sehingga program yang dikembangkan layak dijadikan sebagai media pembelajaran dan dapat dimanfaatkan dalam pembelajaran fisika pokok bahasan impuls dan momentum untuk siswa SMA kelas XI.

Kata kunci: Pengembangan, Media Pembelajaran, Microsoft Excel 20I0, Impuls dan Momentum

\section{Pendahuluan}

Dewasa ini banyak hal yang dilakukan pemerintah untuk memajukan kualitas dan mutu pendidikan, Diantaranya adalah terjadinya perubahan kurikulum. Perubahan kurikulum yang terjadi hampir setiap tahun ini bertujuan untuk membentuk generasi penerus bangsa serta sumber daya manusia (SDM) yang berkualitas, cerdas, serta mempunyai iman dan takwa yang kuat. Setiap kali terjadi pergantian menteri pendidikan selalu diikuti dengan pergantian kurikulum. Perubahan kurikulum yang terjadi setiap tahun bagaikan sebuah solusi singkat pemerintah untuk meningkatkan mutu pendidikan di Indonesia, akan tetapi tidak diikuti dengan peningkatan sarana dan prasarana pendidikan serta peningkatan kualitas guru. Kurangnya pemerataan sarana dan prasarana pendidikan merupakan hambatan utama dalam peningkatan kualitas pendidikan. Hal ini menjadi penting karena semakin baik sarana dan prasarana dalam suatu instansi pendidikan, maka akan semakin mudah bagi instansi tersebut untuk mengembangkan kualitas mutu pendidikan. Sanjaya $[\mathrm{I}]$ menyatakan Terdapat beberapa keuntungan bagi sekolah yang memiliki kelengkapan sarana dan prasarana. Pertama, kelengkapan sarana dan prasarana dapat menumbuhkan gairah dan motivasi guru mengajar. Mengajar dapat dilihat dari dua dimensi, yaitu sebagai proses penyampaian materi pembelajaran dan sebagai proses pengaturan lingkungan 
yang dapat merangsang siswa untuk belajar. Apabila mengajar dipandang sebagai proses penyampaian materi, maka dibutuhkan sarana dan pembelajaran berupa alat dan bahan yang dapat menyalurkan pesan secara efektif dan efesien. Kedua, kelengkapan sarana dan prasarana dapat memberikan berbagai pilihan bagi siswa untuk belajar. Setiap siswa pada dasarnya memiliki gaya belajar yang berbeda. Siswa yang bertipe auditif akan lebih mudah belajar melalui pendengaran; sedangkan tipe siswa yang visual akan lebih mudah belajar melalui penglihatan. Walaupun pada kenyataanya ada sebuah prestasi dalam keterbatasan sarana dan prasarana pendidikan, tetapi hal ini tidak bisa menjadi acuan dalam instansi pendidikan.

Kualitas guru juga merupakan faktor utama dalam peningkatan kualitas pendidikan. Guru yang berkualitas akan dapat memanfaatkan keterbatasan sarana sebagai senjata utama dalam mengajar. Begitu juga sebaliknya guru yang tidak berkompeten akan sulit untuk memanfaatkan sarana dan prasarana yang memadai untuk meningkatkan kualitas pendidikan. Selain itu, kurangnya pelatihanpelatihan teknologi bagi guru juga mempengaruhi kualitas guru dalam mengajar. Sehingga guru dalam proses belajar mengajar hanya mengandalkan materi belaka tanpa diikuti dengan media-media pembelajaran serta teknologi dalam mengajar. Padahal kita ketahui bahwa faktor kejenuhan dalam belajar dapat terjadi pada siswa apabila dalam proses pembelajaran tidak diikuti dengan inovasi-inovasi baru dalam mengajar, sehingga dampak terburuk dari hal ini adalah akan terjadi kurangnya minat belajar siswa dalam menyimak pelajaran sertaterja dipenurunan prestasi belajar siswa di sekolah.

Impulsdan momentum merupakan mata pelajaran fisika yang dalam proses pembelajaran materinya memerlukan penalaran serta gambaran nyata dalam kehidupan seharihari. Kebanyakan siswa kurang memahami materi impuls dan momentum apabila hanya dijelaskan tanpa diberi gambaran nyata dalam kehidupan sehari-hari. Siswa cenderung hanya terpaku pada rumus semata tanpa diikuti dengan penalaran dalam pemyelesaian masalah. Oleh karena itu diperlukan media pembelajaran yang dapat mempermudah dalam mempelajari materi impuls dan momentum. Micrososft Excel 2010 diharapkan dapat membantu mempermudah dalam mempelajari impuls dan momentum. Keunggulan Micrososft Excel sebagai media pembelajaran terletak pada kemudahan pembuatan serta pengoperasiannya.

\section{Kajian Pustaka}

\section{Media Pembelajaran}

Kata media berasal dari bahasa Latin dan bentuk jamak dari dari kata medium yang secara harfiah berarti perantara atau pengantar [2].

Menurut Bambang Warsita [3] media adalah perantara atau pengantar pesan dari si pengirim (komunikator atau sumber/source) kepada si penerima (komunikan atau (audience/receiver). Sedangkan media pembelajaran adalah sarana komunikasi yang digunakan untuk menyampaikan pesan atau bahan pembelajaran. Gagne [2] menyatakan bahwa media adalah berbagai jenis komponen dalam lingkungan siswa yang dapat merangsangnya untuk belajar. Sementara itu Brigg [2] berpendapat bahwa media adalah segala alat fisik yang dapat menyajikan pesan serta dan merangsang siswa untukbelajar.

Dari beberapa definisi diatas dapat disimpulkanbahwa media pembelajaran adalah segala sesuatu yang dapat digunakan untuk menyalurkan pesan dari pengirim ke penerima sehingga dapat merangsang pikiran, perasaan, perhatian, dan minat serta perhatian siswa sedemikian rupa sehingga terjadinya proses belajarmengajar.

Menurut Mulyanta [4] kriteria media pembelajaran yang baik idealnya meliputi beberapa hal, yakni:

a. Kesesuaian atau relevensi, artinya media pembelajaran harus sesuai dengan kebutuhan belajar, rencana kegiatan belajar, program kegiatan belajar, tujuan belajar dan karakteristik peserta didik.

b. Kemudahan, artinya semua isi pembelajaran melalui media harus mudah dimengerti, dipelajari atau dipahami oleh peserta didik, dan sangat operasional dalam penggunaanya.

c. Kemenarikan, artinya media pembelajaran harus mampu menarik maupun merangsang perhatin peserta didik, baik tampilan, pilihan warna, maupun isinya. Uraian isi tidak membingungkan serta dapat menarik minat peserta didik untuk menggunakan media tersebut.

Kemanfaatan, artinya isi dari media pembelajaran harus bernilai atau berguna, mengandung manfaat bagi pemahaman materi pembelajaran.

\section{Microsoft Excel 2010}

Microsoft Excel 2010 atau Microsoft Office Excel merupakan sebuah program aplikasi lembar kerja spreadsheet yang dibuat dan didistribusikan oleh Microsoft untuk system operasi Microsoft windows dan mac OS.Microsoft Excel 2010 merupakan penerus dari Microsoft Excel 2007. Secara sepintas tidak ada perbedaanantara Excel 2007 dan Excel 2010, namun 
menurut Winaryu Bagus [5] beberapa kelebihan Microsoft Excel 2010 yakni :

a. Lebih ringan

b. Hadirnya menu "file" kembali

c. Smart-Art dan template terbaru

d. Save As lebih variatif

e. Memiliki Screenshot capture, yakni sebuah fasilitas yang memungkinkan mengambil capture gambar

f. Fasilitas removal background yakni bias dengan mudah menghapus Background yang ada di shape,dll.

Adanya fasilitas Equation yang memudahkan dalam menginput rumus-rumus mata pelajaran matematika.

\section{Impuls dan Momentum}

Impuls adalah hasil kali antara besaran vektor gaya impulsif rata-rata $(\bar{F})$ dengan besaran skalar selang waktu $(\Delta t)[6]$. Impuls termasuk dalam besaran vector dan diberi lambing $I$.

Secara umum impuls dirumuskan sebagai berikut:

$$
I=\bar{F} \Delta t=\bar{F}\left(t_{2}-t_{1}\right)
$$

Momentum didefinisikan sebagai ukuran kesukaran memberhentikan suatu benda [6]. Momentum juga dapat didefinisikan sebagai hasil kali antara besaran skalar massa dengan besaran vektor kecepatan. Sehingga, momentum termasuk besaran vektor karena merupakan perkalian antara besaran skalar dengan besaran vektor.

Rumusan umum momentum adalah:

$$
p=m v
$$

\section{Metode Penelitian/Eksperimen}

\section{Prosedur Pengembangan}

Pada penelitian ini prosedur yang digunakan mengacu pada model pengembangan ADDIE yaitu Analysis (analisis), Design (Desain), Development (Pengembangan), Implementation (Implementasi), dan Evalution (evaluasi). Langkah-langkah yang ditempuh diantaranya:

\section{Desain Uji Coba}

Desain angket yang dibuat pada penelitian menggunakan format respon empat poin dari Skala Likert. Penentuan skala Likert yakni untuk skala yang berarah positif akan mempunyai kemungkinan-kemungkinan skor 4 bagi sangat setuju (SS), Skor 3 bagi setuju (S), skor 2 bagi kurang setuju (KS), dan Skor I bagi tidak setuju (TS).

\section{Subjek Penelitian}

Subjek Ujicoba adalah 5 dosen sebagai ahli materi dan ahli media serta I5 siswa SMAN I Semitau sebagai pengguna. Daftar Nama Responden untuk Uji materi, media, serta pengguna sebagai berikut:

\begin{tabular}{clc}
\multicolumn{3}{c}{ Tabel I. Nama Responden Uji Materi } \\
\hline No. & \multicolumn{1}{c}{ Nama } & \multicolumn{1}{c}{ Profesi } \\
\hline \hline I. & NanangSuwondo, M.Pd Si & Dosen Pendidikan Fisika UAD \\
2. & Eko Nursulistiyo, M.Pd & Dosen Pendidikan Fisika UAD \\
3. & Fajar Fitri, M.Pd.Si & Dosen Pendidikan Fisika UAD \\
\hline
\end{tabular}

Tabel 2. Nama Responden Uji Media

\begin{tabular}{cll}
\hline No. & \multicolumn{1}{c}{ Nama } & \multicolumn{1}{c}{ Profesi } \\
\hline \hline I. & Dr. Ir. Dwi Sulisworo, M.T & Dosen Pendidikan Fisika UAD \\
2. & Rachmad Resmiyanto & Dosen Pendidikan Fisika UAD \\
\hline
\end{tabular}

Tabel 3. Nama Responden Uji Pengguna

\begin{tabular}{cll}
\hline No. & \multicolumn{1}{c}{ Nama } & \multicolumn{1}{c}{ Profesi } \\
\hline \hline I. & Edi Candra & Siswa SMA \\
2. & EriJuniarti & Siswa SMA \\
3. & Dwi Fitri Budiyanti & Siswa SMA \\
4. & Dwi Fitri Budiyanti & Siswa SMA \\
5. & Apriyanti & Siswa SMA \\
6. & Erma Maria Imakulata K. & Siswa SMA \\
7. & Krista Natalia & Siswa SMA \\
8. & UndryWardana & Siswa SMA \\
9. & Dian Wulandari & Siswa SMA \\
I0. & Hiwilma Cleta Ernawati & Siswa SMA \\
II. & Fransiska Marsela & Siswa SMA \\
I2. & Dwi Suri Pangestu & Siswa SMA \\
I3. & Tsaniya Rahma Saleha & Siswa SMA \\
I4. & Erwin Susanto & Siswa SMA \\
I5. & Eka Nurmuqomah & Siswa SMA \\
\hline
\end{tabular}

\section{Instrumen Pengumpulan Data}

Instrumen penelitian adalah alat-alat yang digunakan untuk pengumpulan data yang berkaitan dengan penelitian yang sedang dilakukan. Dalam penelitian ini instrumen yang digunakan adalah sebagai berikut :
a. Angket ahli media
b. Angket ahli materi (fisika)
c. Angket Pengguna

\section{Teknis analisis data}

Untuk mengalisis data hasil angket maka dilakukan langkah-langkah sebagai berikut :

a. Mengolah hasil angket yang diperoleh dengan memberikan skor yang sesuai dengan bobot nilai yang telah ditentukan sebelumnya.

b. Membuat tabulasi data variabel hasil penelitian

c. Menghitung presentase variabel dengan menggunakan rumus: 


$$
P=\frac{S}{S_{m}} \times 100 \%
$$

Keterangan :

$P \quad:$ tingkat kelayakan program

$S \quad$ : jumlah skor total yang diperoleh

$S_{m}$ : jumlah skor maksimal

Tahapan yang selanjutnya dilakukan diantaranya adalah:

a. Menentukan nilai skor tertinggi yakni 100\%

b. Menentukan skor terendah yaitu $0 \%$

c. Menentukan empat daerah interval yakni baik, cukup baik, kurang baik dan tidak baik

d. Membagi skala menjadi empat daerah interval dengan kriteria sebagai berikut:

$0 \%-25 \%=$ tidak baik

$26 \%-50 \%=$ kurang baik

$51 \%-75 \%=$ cukup baik

$76 \%-100 \%=$ baik

\section{Hasil Penelitian dan Pembahasan}

\section{Ahli Materi}

Analisis angket uji materi diperoleh dari 3 orang responden yakni tiga orang dosen pendidikan fisika. Analisis data ahli materi disajikan pada tabel berikut:

Tabel 4. Aspek Penilaian ahli materi

\begin{tabular}{clc}
\hline No & \multicolumn{1}{c}{ Aspek Penilaian } & Persentase Penilaian \\
\hline I. & Kesesuaian terhadap materi & $78,78 \%$ \\
2. & Bahasa & $77,08 \%$ \\
3. & Kelayakan penyajian & $81,25 \%$ \\
4. & Manfaat & $77,78 \%$ \\
\hline
\end{tabular}

Berdasarkan hasil analisis angket ahli materi mengenai media pembelajaran berbasis Microsoft Excel 2010 pada pokok bahasan impuls dan momentum yang telah dikembangkan menghasilkan persentase sebesar 78,72\% dan tergolong dalam kategori baik.

Berikut ini disajikan sebuah diagram hasil analisis data oleh ahli materi:

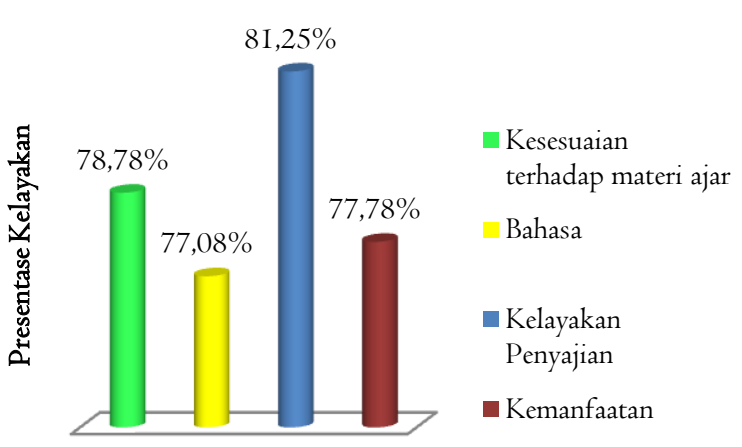

Aspek Penilaian

Gambar I. Diagram Presentase hasil penilaian Ahli Materi

\section{Ahli Media}

Analisis angket uji media diperoleh dari 2 orang responden yakni satu orang dosen pendidikan fisika dan satu orang dosen pascasarjana Universitas Ahmad Dahlan yang memiliki keahlian dalam pengembangan media pembelajaran. Analisis data ahli media disajikan pada tabel berikut:

Tabel 5. Aspek Penilaian ahli media

\begin{tabular}{llc} 
No. & \multicolumn{1}{c}{ Aspek Penilaian } & Persentase Penilaian \\
\hline \hline I. & Layout Media & $72,50 \%$ \\
2. & Kemudahan dalam Pengoperasian & $92,18 \%$ \\
3. & Manfaat & $70,83 \%$ \\
\hline
\end{tabular}

Berdasarkan angket yang diberikan pada ahli media terhadap media pembelajaran berbasis Microsoft Excel 2010 pada pokok bahasan impuls dan momentum yang telah dianalisis menghasilkan persentase sebesar 78,50\% dan termasuk dalam kategori baik.

Berikut ini disajikan sebuah diagram hasil analisis data oleh ahli media:

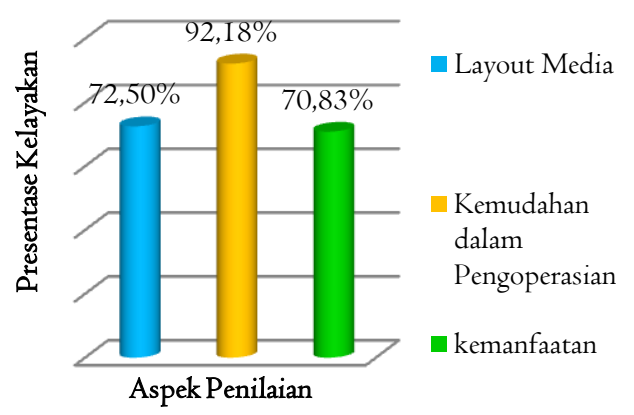

Gambar 2. Diagram Presentase Hasil Penilaian Ahli Media 


\section{Pengguna}

Data dari pengguna diperoleh dari I5 orang siswa SMA Negeri I Semitau. Analisis data ahli materi disajikan pada tabel berikut:

Tabel 6. Aspek Penilaian Pengguna

\begin{tabular}{ccc}
\hline No. & Aspek Penilaian & Persentase Penilaian \\
\hline I. & Tampilan Program & $76,66 \%$ \\
2. & Penggunaan Bahasa & $76,66 \%$ \\
\hline
\end{tabular}

Berdasarkan angket yang diberikan pada pengguna terhadap media pembelajaran berbasis Microsoft Excel 2010 pada pokok bahasan impuls dan momentum yang telah dianalisis menghasilkan persentase sebesar 76,66\% dan termasuk dalam kategori baik.

Berikut ini disajikan sebuah diagram hasil analisis data oleh ahli materi:

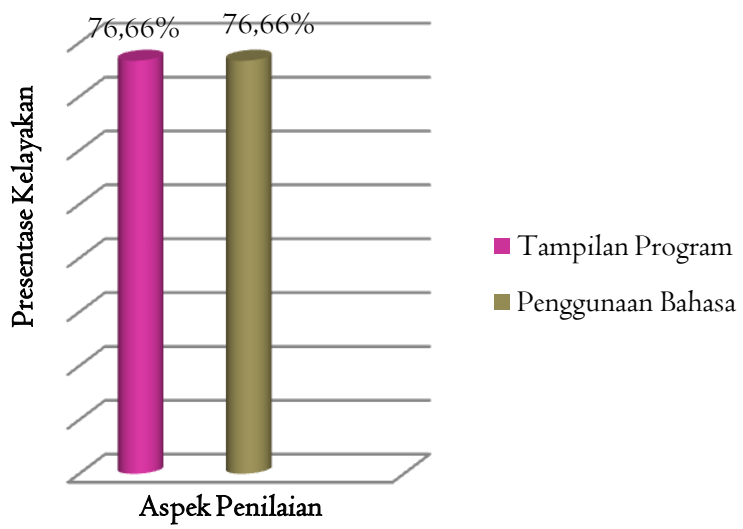

Gambar 3. Diagram Presentase hasil penilaian Pengguna

\section{Kesimpulan}

Dari hasil penelitian dan pembahasan yang dilakukan dapat diambil kesimpulan sebagai berikut:

I. Telah dibuat media pembelajaran fisika SMA kelas XI menggunakan Microsoft Excel 2010 pada pokok bahasan Impuls dan momentum.

2. Berdasarkan hasil pengujian yang dilakukan terhadap ahli materi diperoleh persentase sebesar $78,72 \%$ atau termasuk dalam kategori baik. Berdasarkan hasil pengujian yang dilakukan terhadap ahli media diperoleh persentase sebesar 78,50\% atau termasuk dalam kategori baik. Berdasarkan hasil pengujian yang dilakukan terhadap pengguna diperoleh persentase sebesar $76,66 \%$ atau termasuk dalam kategori baik.

\section{Kepustakaan}

[I] Sanjaya, wina (2013). Perencanaan \& desain sistem pembelajaran. Jakarta: Kencana Prenadamedia Group

[2] Sadiman, Arief, Dkk. (20I2).Media pendidikan pengertian, pengembangan, dan pemanfaatannya. Jakarta: PT Raja Grafindo Persada.

[3] Warsita, Bambang. (2008). Teknologi Pembelajaran landasan dan aplikasinya. Jakarta: Rineka Cipta.

[4] Mulyanta,St,dkk.(2009).Tutorial membangun multimedia interaktif media pembelajaran. Yogyakarta: Universitas Atma Jaya Yogyakarta.

[5] Winahyu, Bagus. (2012). Belajar mudah \& cepat Microsoft Excel 20IO. Yogyakarta: Pustaka Baru Press.

[6] kanginan, Marthen. (2013). Fisika untuk SMA/MA kelas XI. Jakarta: Erlangga. 